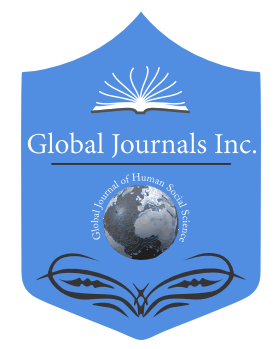

\title{
Empirical Research on Occupational Adaptation of Graduates from Higher Vocational Colleges and Educational Considerations
}

By Su Yunxia \& Sun Minggui

Donghua University

Abstract- Through empirical research, this paper puts forward and validates the theoretical model of occupational adaptation for vocational college graduates, which consists of four dimensions: occupational cognitive adaptation, occupational psychological adaptation, occupational skills adaptation, interpersonal and professional environment adaptation. The study finds that the overall level of occupational adaptation of graduates from higher vocational colleges is low; occupational adaptation is affected by years of graduation, and income satisfaction level; occupational psychological adaptation is affected by years of graduation, unit property, and income satisfaction level; interpersonal and professional environment adaptation is affected by income satisfaction level. Therefore, higher vocational colleges need to deepen the work of vocational guidance, improve the training mode of talents in higher vocational colleges, strengthen the mental health education of students in colleges, and guide students to establish correct values.

Keywords: higher vocational college; graduates; occupational adaptation; education.

GJHSS-G Classification: FOR Code: 139999

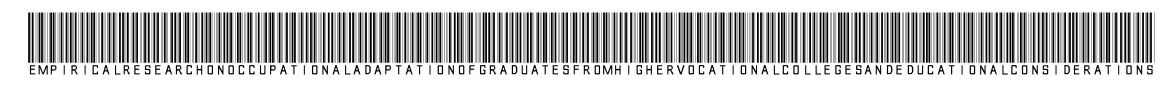

Strictly as per the compliance and regulations of:

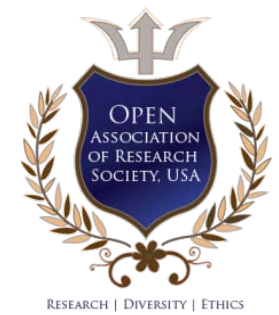

(C) 2019. Su Yunxia \& Sun Minggui. This is a research/review paper, distributed under the terms of the Creative Commons Attribution-Noncommercial 3.0 Unported License http://creativecommons.org/licenses/by-nc/3.0/), permitting all non-commercial use, distribution, and reproduction in any medium, provided the original work is properly cited. 


\title{
Empirical Research on Occupational Adaptation of Graduates from Higher Vocational Colleges and Educational Considerations
}

\author{
Su Yunxia ${ }^{\alpha} \&$ Sun Minggui ${ }^{\sigma}$
}

\begin{abstract}
Through empirical research, this paper puts forward and validates the theoretical model of occupational adaptation for vocational college graduates, which consists of four dimensions: occupational cognitive adaptation, occupational psychological adaptation, occupational skills adaptation, interpersonal and professional environment adaptation. The study finds that the overall level of occupational adaptation of graduates from higher vocational colleges is low; occupational adaptation is affected by years of graduation, and income satisfaction level; occupational psychological adaptation is affected by years of graduation, unit property, and income satisfaction level; interpersonal and professional environment adaptation is affected by income satisfaction level. Therefore, higher vocational colleges need to deepen the work of vocational guidance, improve the training mode of talents in higher vocational colleges, strengthen the mental health education of students in colleges, and guide students to establish correct values.
\end{abstract}

Keywords: higher vocational college; graduates; occupational adaptation; education.

\section{INTRODUCTION}

$(1$ ince the State Council issued the decision on deepening education reform and comprehensively promoting quality education in June 1999, higher vocational education (including vocational colleges) has gradually developed into half of Chinese higher education, which has accelerated the popularization process of higher education. However, since 2002, the graduates have been employed one after another after the enrollment expansion of colleges and universities in China. The employment pressure and cruel employment reality make many college students blindly choose "employment first and selection second" and the phenomenon of frequent "job hopping" of college students' employees in the period of occupational adaptation occurs (Xiao, 2014). From the perspective of new employees' performance in the workplace, new employees generally have problems such as difficult to adapt to the work intensity, unable to properly handle interpersonal relationships, and with high psychological pressure, which can attribute to occupational adaptation.The decision of the State Council on accelerating the development of modern vocational

Author a: Shanghai Publishing and Printing College, Shanghai, China. Author o: Donghua University, Shanghai, China.

e-mail: sunnysu545@126.com education (GF [2014] No. 19) emphasizes that vocational education should serve the needs, take employment as the guidance, connect the teaching process with the production process, and focus on improving the employability of young people. Therefore, in the context of economic and social transformation and industry upgrading, as education type closely connected with industry and market, it is necessary to pay attention to the improvement of students' employability. It becomes quite important for vocational colleges to cultivate students' occupational adaptability before employment. In this context, there is great theoretical and practical implication to investigate the adaptation of college graduates. It can expand the research field of adaptation, reveal the problems of adaptation of college graduates and promote the employment education of colleges.

\section{il. A Study on the Structure of Occupational Adaptation of Graduates from Higher Vocational Colleges}

Review of the Concept, Structure and Measurement of Occupational Adaptation

Making a comprehensive survey of the relevant research of domestic and foreign scholars, scholars have summed up and interpreted the concept of occupational adaptation from three perspectives. The first is from the process theory/state theory Fang, 2001; Dai, 2002). The second is from the interaction theory/theory of individual active response (Pan, 2013; Veenman, 1984). The third is from socialization/content of cultural adaptation (Yuan et al., 1992; Chen, 1999). Domestic and foreign scholars have a different understanding of occupational adaptation, which make the measurement methods of adaptation different. Measurement research abroad mainly includes Campbell's six-dimensional structure (1990), Huebner's four-dimensional structure (2002) based on Campbell's research, and Savickas and Porfeli's four-dimensional structure (2012). According to different research objects, there are different measurement methods in domestic measurement research. For example, there are fivedimensional structure (Wang, 2018) and threedimensional structure (Yin, 2015) for the measurement 
of occupational adaptation with teachers as the research object, and four-dimensional structure (Tang, 2009) for the adaptation with college students as the research object.

Theoretical Conception and Empirical Verification of Occupational Adaptation Structure of Higher Vocational College Graduates

Based on the three research perspectives of domestic and foreign scholars on occupational adaptation, this study holds that the occupational adaptation of vocational college graduates is the process and result of the interaction between the individual professional quality and professional requirements as well as the working environment to achieve a harmonious balance, and the degree to which graduates meet the work itself and role. In this study, the occupational adaptation of vocational college graduates is defined as four factors: occupational cognitive adaptation, occupational psychological adaptation, occupational skills adaptation, interpersonal and professional environment adaptation. Because higher vocational students, undergraduates, and postgraduates belong to the subject of higher education in China, they have similar cognition to the occupational adaptation to some extent. Therefore, this study uses 22 items of adaptation compiled by Tang (2009) as the initial scale to measure the adaptation of higher vocational college graduates. Likert 5 scores are used in the scale, with options from "very inconsistent" to "very consistent" scoring 1 to 5 , respectively.

Because the higher vocational education is employment-oriented, the students of vocational colleges have been in the practice state in the second semester of the third grade. Therefore, the graduates whose graduation time is $0-3$ years are selected as the research object of this paper. The initial scale was predicted in four higher vocational colleges in Shanghai. Two hundred questionnaires were issued, 182 of which were recovered, with a recovery rate of $91 \%$. Among them, 169 were valid questionnaires, with an effective rate of $93 \%$. The statistical software SPSS21. 0 was used to conduct exploratory factor analysis on 22 items of occupational adaptation. If the factor load of the measurement item after rotation is less than 0.50 or the load on both factors is larger than 0.50, this study will delete the measurement item. In the end, 14 measurement items are retained. Using the factor analysis method of the orthogonal rotation axis (KMO value is $0.759, \chi^{2}$ of Bartlett sphere test is 569.586 $(d f=91)$, sig=0.000), four factors are obtained. The relevant statistics of factor analysis are shown in Table 1.

Table 1: Items and Factor Analysis of Occupational Adaptation Scale for Higher Vocational College Graduates.

\begin{tabular}{|c|c|c|c|c|}
\hline \multirow[b]{2}{*}{ Items of Occupational Adaptation } & \multicolumn{4}{|c|}{ Factor Loading $^{\mathrm{a}}$} \\
\hline & $\begin{array}{l}\text { Occupational } \\
\text { Cognitive } \\
\text { Adaptation }\end{array}$ & $\begin{array}{l}\text { Occupational } \\
\text { Psychological } \\
\text { Adaptation }\end{array}$ & $\begin{array}{l}\text { Occupational } \\
\text { Skills } \\
\text { Adaptation }\end{array}$ & $\begin{array}{c}\text { Interpersonal and } \\
\text { Professional } \\
\text { Environment } \\
\text { Adaptation } \\
\end{array}$ \\
\hline I have clear career goals and career plans & 0.572 & -0.432 & -0.230 & 0.056 \\
\hline $\begin{array}{l}\text { I can face difficulties calmly because I believe in my } \\
\text { ability to deal with problems }\end{array}$ & 0.862 & -0.092 & 0.037 & -0.054 \\
\hline $\begin{array}{l}\text { When facing a difficult problem, I can usually find } \\
\text { several solutions }\end{array}$ & 0.821 & -0.044 & 0.080 & -0.021 \\
\hline I am confident in achieving my work goals & 0.810 & 0.077 & -0.097 & -0.175 \\
\hline I am often confused about my work and prospects & -0.218 & 0.763 & 0.196 & 0.106 \\
\hline I often have the idea of changing my job & -0.026 & 0.862 & 0.088 & 0.200 \\
\hline I am often tired of my work & 0.067 & 0.757 & 0.197 & 0.312 \\
\hline I often feel weak and uncomfortable & -0.037 & 0.111 & 0.800 & 0.003 \\
\hline I feel a lot of pressure at work & -0.036 & 0.244 & 0.789 & 0.168 \\
\hline $\begin{array}{c}\text { The workload is too large, the work pace is too fast, } \\
\text { and I feel very tired }\end{array}$ & -0.124 & 0.027 & 0.697 & 0.346 \\
\hline $\begin{array}{l}\text { The knowledge learned by the school falls behind the } \\
\text { needs of practical application }\end{array}$ & 0.087 & 0.144 & 0.514 & 0.222 \\
\hline I feel at a loss about the relationships around me & 0.111 & 0.249 & 0.258 & 0.674 \\
\hline $\begin{array}{c}\text { It's hard for me to change my role from a student to a } \\
\text { professional person }\end{array}$ & -0.147 & 0.119 & 0.114 & 0.835 \\
\hline Career stability is too bad, I have no sense of security & -0.217 & 0.229 & 0.269 & 0.712 \\
\hline Initial eigenvalue & 4.471 & 2.334 & 1.342 & 1.094 \\
\hline $\begin{array}{l}\text { Variance contribution rate of extraction\%(Cumulative } \\
66 \% \text { ) }\end{array}$ & 31.93 & 16.67 & 9.59 & 7.81 \\
\hline Variance contribution rate after rotation\% & 18.27 & 16.59 & 16.56 & 14.58 \\
\hline Number of items & 4 & 3 & 4 & 3 \\
\hline Factor Cronbach $\alpha$ value & 0.886 & 0.905 & 0.830 & 0.847 \\
\hline
\end{tabular}


A: Extraction method is the principal component method; the rotation extraction method: Kaiser normalization maximum variation method; rotation axis converges to 5 iterations. If the factor load is larger than 0.5 , the font should be bold.

According to the test items of each factor, they are named "occupational cognitive adaptation," "occupational psychological adaptation," "occupational skills adaptation," "and interpersonal and professional environment adaptation." The reliability of the four factors is above 0.8, and they all have good content validity. The Cronbach $\alpha$ coefficient of the total scale is 0.819, which meets the requirements of the development reliability of the scale (Nunnally, 1978). Correlation analysis showed that there was a significant correlation between occupational adaptation and each factor, the correlation coefficient was between 0.5750.772, and each could reflect the connotation of occupational adaptation; mean while, the correlation coefficient of each is between 0.151-0.418, which belongs to the middle and low degree correlation, indicating that there are both convergence validity and discriminative validity.

This study entrusted 8 teachers to another eight vocational colleges in Shanghai to collect 341 valid questionnaires from graduates, covering graduates of science and engineering, literature and history, art, medicine, and agriculture disciplines as much as possible.Amos21.0 was used for confirmatory factor analysis. The results showed that $\chi^{2} / \mathrm{df}=3.29<5$, RMSEA $=0.074<0.08, \mathrm{CFI}, \mathrm{GFI}$ and NFI are all above 0.9 , the theoretical model has a good fit, and the four- dimensional structure of occupational adaptation of vocational college graduates is verified.

\section{ili. A Study on the Characteristics of Occupational Adaptation of Graduates From Higher Vocational Colleges}

Spss 21.0 was used to analyze the 341 valid questionnaire data to study the characteristics of occupational adaptation of vocational college graduates.

The General Situation of Occupational Adaptation of Vocational College Graduates

The overall level of mean value of the occupational adaptation of vocational college graduates is low $(M=3.22, S D=0.56)$. The order of the scores of each factor is interpersonal and professional environment adaptation $(M=3.45, S D=0.68)$, cognitive adaptation $\quad(M=3.28, \quad S D=0.71)$, skills adaptation $(M=3.11, \quad S D=0.76), \quad$ psychological adaptation $(M=3.06, S D=0.76)$. The average value of occupational adaptation of vocational college graduates and that of its various factors is lower than four scores, which shows that the overall adaptation of college graduates is in the lower middle level.

\section{Occupational Adaptation of Graduates of Different Genders}

T-test shows that male $(M=3.29, S D=0.55)$ scores slightly higher than female $(M=3.20, S D=0.57)$, and there is no significant difference $(P>0.05)$ in terms of occupational adaptation (see Table 2).

Table 2: The Mean, Standard Deviation and T Test of Occupational Adaptation and Its Factors of Graduates of Different Genders.

\begin{tabular}{|c|c|c|c|}
\hline & \multicolumn{2}{|c|}{ Gender(M \pm SD $)$} & \multirow{2}{*}{ T Value } \\
\cline { 2 - 3 } & Male(N=157) & Female(N=184) & \\
\hline Occupational Adaptation & $3.29 \pm 0.55$ & $3.20 \pm 0.57$ & 0.671 \\
\hline Cognitive Adaptation & $3.38 \pm 0.67$ & $3.24 \pm 0.73$ & 0.855 \\
\hline Psychological Adaptation & $3.23 \pm 0.76$ & $3.00 \pm 0.89$ & 1.225 \\
\hline Skills Adaptation & $3.19 \pm 0.70$ & $3.10 \pm 0.79$ & 0.536 \\
\hline Interpersonal and Professional Environment Adaptation & $3.35 \pm 0.77$ & $3.49 \pm 0.93$ & -0.737 \\
\hline
\end{tabular}

Occupational Adaptation of Graduates with Different Graduation Years

Univariate analysis of variance shows that there are significant differences in occupational adaptation and psychological adaptation among graduates with different graduation years. With the increase of graduation years, the interpersonal and professional environment adaptation of higher vocational college graduates has gradually improved.Occupational adaptation, occupational cognitive adaptation, psychological adaptation, and occupational skills adaptation all reach the lowest level in one year after graduation; however, the two-year and three-year graduates' adaptation, cognitive adaptation, psychological adaptation and skills adaptation are higher than those of the first year graduates, moreover, there is a significant difference between the adaptation of three-year graduates and that of two-year graduates $(P<0.05)$, and there is a difference between the psychological adaptation of the two-year and three-year graduates and that of those just graduated $(P<0.1)$ (see Table 3). 
Table 3: Analysis of Mean, Standard Deviation and Variance of Vocational Adaptation and Factors of Graduates with Different Years of Graduation.

\begin{tabular}{|c|c|c|c|c|c|c|}
\hline & \multicolumn{4}{|c|}{ Different Years of Graduation(M \pm SD) } & \multirow{2}{*}{$\begin{array}{c}F \\
\text { Value }\end{array}$} & \multirow[b]{2}{*}{ Scheffe } \\
\hline & $\begin{array}{c}\text { Just } \\
\text { Graduated(N=78) }\end{array}$ & $\begin{array}{c}\text { One-year } \\
\text { Graduates }(\mathrm{N}=85)\end{array}$ & $\begin{array}{c}\text { Two-year } \\
\text { Graduates }(\mathrm{N}=98)\end{array}$ & $\begin{array}{c}\text { Three-year } \\
\text { Graduates }(\mathrm{N}=80)\end{array}$ & & \\
\hline $\begin{array}{l}\text { Occupational } \\
\text { Adaptation }\end{array}$ & $3.07 \pm 0.56$ & $2.96 \pm 0.50$ & $3.26 \pm 0.40$ & $3.38 \pm 0.70$ & $3.030^{* *}$ & $D>C$ \\
\hline Cognitive Adaptation & $3.18 \pm 0.69$ & $3.00 \pm 0.70$ & $3.34 \pm 0.69$ & $3.47 \pm 0.76$ & 1.518 & \\
\hline $\begin{array}{l}\text { Psychological } \\
\text { Adaptation }\end{array}$ & $2.87 \pm 0.83$ & $2.64 \pm 0.84$ & $3.28 \pm 0.68$ & $3.21 \pm 0.74$ & $2.602^{*}$ & $D>A, C>A$ \\
\hline Skills Adaptation & $2.98 \pm 0.68$ & $2.91 \pm 0.78$ & $3.28 \pm 0.71$ & $3.19 \pm 0.91$ & 1.269 & \\
\hline $\begin{array}{l}\text { Interpersonal and } \\
\text { Professional } \\
\text { Environment } \\
\text { Adaptation }\end{array}$ & $3.28 \pm 0.85$ & $3.30 \pm 0.76$ & $3.59 \pm 0.85$ & $3.60 \pm 0.92$ & 1.069 & \\
\hline
\end{tabular}

${ }^{* * *} 、{ }^{* *} 、{ }^{*}$ passed the test at the significance level of $1 \%, 5 \%$ and $10 \%$ (i.e., ${ }^{* \star *} \mathrm{P}<0.01,{ }^{* \star} \mathrm{P}<0.05,{ }^{*} \mathrm{P}<0.1$ );

$\mathrm{A}=$ Just Graduated, $\mathrm{B}=$ One-year Graduates, $\mathrm{C}=$ Two-year Graduates, $\mathrm{D}=$ Three-year Graduates

Occupational Adaptation of Graduates Working in Units of Different Natures

Univariate analysis of variance shows that there are significant differences in occupational, psychological adaptation among graduates working in units of different natures. The unit nature of the average score of adaptation from high to low is government agencies, government-affiliated institutions or social organizations, joint ventures, private enterprises, foreign-funded enterprises, state-owned enterprises, and self-employed enterprises. The unit nature of the average score of occupational cognitive adaptation from high to low is joint ventures, government agencies, governmentaffiliated institutions or social organizations, private enterprises, state-owned enterprises, foreign-funded enterprises, and self-employed enterprises. The unit nature of the average score of psychological adaptation from high to low is government-affiliated institutions or social organizations, government agencies, private enterprises, foreign-funded enterprises, self-employed enterprises, joint ventures, state-owned enterprises.Also, there is a significant difference between the psychological adaptation of graduates working in government agencies and state-owned enterprises and that of graduates working in foreign-funded enterprises $(P<0.05)$. The unit nature of the average score of occupational skills adaptation from high to low is government agencies, private enterprises, selfemployed enterprises, government-affiliated institutions or social organizations, state-owned enterprises and foreign-funded enterprises, joint ventures. The unit nature of the average score of interpersonal and professional environment adaptation from high to low is government agencies, joint ventures, foreign-funded enterprises, private enterprises, state-owned enterprises, government-affiliated institutions or social organizations, and self-employed enterprises (see Table 4).

Table 4: Analysis of Mean, Standard Deviation and Variance of Vocational Adaptation and Factors of Graduates Working in Units of Different Natures.

\begin{tabular}{|c|c|c|c|c|c|c|c|c|c|}
\hline & \multicolumn{7}{|c|}{ Unit Nature } & \multirow[b]{2}{*}{$\begin{array}{c}F \\
\text { Value }\end{array}$} & \multirow[b]{2}{*}{ Scheffe } \\
\hline & $\begin{array}{l}\text { Governme } \\
\text { nt } \\
\text { Agencies } \\
(\mathrm{N}=37)\end{array}$ & $\begin{array}{c}\text { Governme } \\
\text { nt-affiliated } \\
\text { Institutions } \\
\text { or Social } \\
\text { Organizati } \\
\text { ons } \\
(\mathrm{N}=48)\end{array}$ & $\begin{array}{l}\text { State-owned } \\
\text { Enterprises } \\
(\mathrm{N}=47)\end{array}$ & $\begin{array}{c}\text { Private } \\
\text { Enterprises } \\
(\mathrm{N}=72)\end{array}$ & $\begin{array}{l}\text { Foreign- } \\
\text { funded } \\
\text { Enterprises } \\
(\mathrm{N}=42)\end{array}$ & $\begin{array}{c}\text { Joint } \\
\text { Ventures } \\
(\mathrm{N}=42)\end{array}$ & $\begin{array}{c}\text { Self- } \\
\text { employed } \\
\text { Enterprises } \\
(\mathrm{N}=53)\end{array}$ & & \\
\hline $\begin{array}{c}\text { Occupational } \\
\text { Adaptation }\end{array}$ & $3.95 \pm 0.51$ & $3.34 \pm 0.36$ & $3.11 \pm 0.89$ & $3.21 \pm 0.48$ & $3.15 \pm 0.55$ & $3.30 \pm 0.34$ & $3.07 \pm 0.64$ & 1.562 & \\
\hline $\begin{array}{l}\text { Cognitive } \\
\text { Adaptation }\end{array}$ & $3.69 \pm 0.63$ & $3.29 \pm 0.80$ & $3.27 \pm 0.83$ & $3.28 \pm 0.57$ & $3.13 \pm 0.59$ & $3.75 \pm 0.50$ & $3.16 \pm 0.62$ & 0.579 & \\
\hline $\begin{array}{c}\text { Psychological } \\
\text { Adaptation }\end{array}$ & $3.58 \pm 0.79$ & $3.71 \pm 0.82$ & $2.76 \pm 0.64$ & $3.00 \pm 0.75$ & $2.90 \pm 0.47$ & $2.78 \pm 0.84$ & $2.79 \pm 0.62$ & 2.743 & $\begin{aligned} A & >E, E \\
& >C\end{aligned}$ \\
\hline $\begin{array}{c}\text { Skills } \\
\text { Adaptation }\end{array}$ & $4.06 \pm 0.69$ & $3.01 \pm 0.70$ & $3.00 \pm 0.54$ & $3.15 \pm 0.68$ & $3.00 \pm 0.56$ & $2.98 \pm 0.76$ & $3.12 \pm 0.76$ & 1.247 & \\
\hline
\end{tabular}




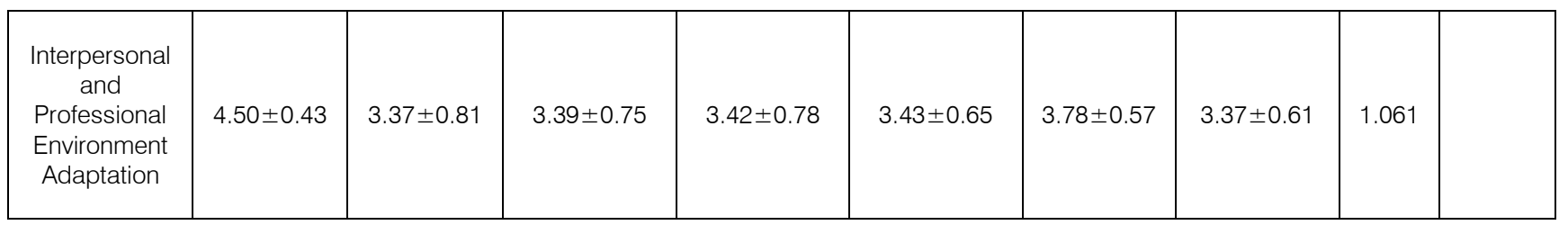

${ }^{* \star \star} 、{ }^{* \star} 、{ }^{*}$ passed the test at the significance level of $1 \%, 5 \%$ and $10 \%$ (i.e., ${ }^{* \star *} \mathrm{P}<0.01,{ }^{* \star} \mathrm{P}<0.05,{ }^{*} \mathrm{P}<0.1$ );

$A=$ Government Agencies, $B=$ Government-affiliated Institutions or Social Organizations, $C=$ State-owned Enterprises, $D=F o r e i g n-f u n d e d$ Enterprises, $\mathrm{E}=$ Foreign-funded Enterprises, $\mathrm{F}=$ Joint Ventures, $\mathrm{G}=$ Self-employed Enterprises

Occupational Adaptation of Graduates with Different Levels of Income Satisfaction

Univariate analysis of variance shows that graduates with different income satisfaction levels have significant differences in occupational adaptation, psychological adaptation, and interpersonal and professional environment adaptation. With the improvement of income satisfaction, the level of occupational adaptation and its factors is showing an upward trend.Also, there is significant difference between the occupational adaptation of graduates with very dissatisfied income and graduates with relatively

Table 5: Analysis of Mean, Standard Deviation and Variance of Occupational Adaptation and Factors of Graduates with Different Income Satisfaction Levels.

\begin{tabular}{|c|c|c|c|c|c|c|c|}
\hline & \multicolumn{5}{|c|}{ Income Satisfaction Levels } & \multirow[b]{2}{*}{ F Value } & \multirow[b]{2}{*}{ Scheffe } \\
\hline & $\begin{array}{c}\text { Very } \\
\text { Dissatisfied } \\
(\mathrm{N}=29)\end{array}$ & $\begin{array}{c}\text { Relatively } \\
\text { Dissatisfied } \\
(\mathrm{N}=57)\end{array}$ & $\begin{array}{l}\text { General } \\
(\mathrm{N}=179)\end{array}$ & $\begin{array}{c}\text { Relatively } \\
\text { Satisfied } \\
(\mathrm{N}=76)\end{array}$ & $\begin{array}{c}\text { Very } \\
\text { Satisfied } \\
(N=0)\end{array}$ & & \\
\hline $\begin{array}{c}\text { Occupational } \\
\text { Adaptation }\end{array}$ & $2.85 \pm 0.62$ & $2.93 \pm 0.53$ & $3.29 \pm 0.40$ & $3.45 \pm 0.59$ & - & $5.755^{* \star *}$ & $C>A, D>C$ \\
\hline Cognitive Adaptation & $3.08 \pm 0.63$ & $3.15 \pm 0.58$ & $3.25 \pm 0.50$ & $3.52 \pm 0.77$ & - & 1.390 & \\
\hline $\begin{array}{c}\text { Psychological } \\
\text { Adaptation }\end{array}$ & $2.56 \pm 0.74$ & $2.65 \pm 0.81$ & $3.11 \pm 0.63$ & $3.44 \pm 0.54$ & - & $4.432^{\star \star \star}$ & $C>A, D>C$ \\
\hline Skills Adaptation & $2.67 \pm 0.86$ & $3.00 \pm 0.78$ & $3.21 \pm 0.62$ & $3.28 \pm 0.88$ & - & 2.960 & \\
\hline $\begin{array}{l}\text { Interpersonal and } \\
\text { Professional } \\
\text { Environment } \\
\text { Adaptation }\end{array}$ & $2.89 \pm 0.76$ & $3.00 \pm 0.81$ & $3.64 \pm 0.71$ & $3.66 \pm 0.68$ & 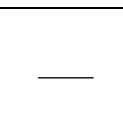 & $4.830^{\star \star *}$ & $C>A, D>A$ \\
\hline
\end{tabular}

${ }^{* * \star}$ 、 ${ }^{* *}$ 、" passed the test at the significance level of $1 \%, 5 \%$ and $10 \%$ (i.e., ${ }^{* * *} \mathrm{P}<0.01,{ }^{* *} \mathrm{P}<0.05,{ }^{*} \mathrm{P}<0.1$ );

$A=$ Very Dissatisfied, $B=$ Relatively Dissatisfied, $C=$ General, $D=$ Relatively Satisfied, $E=$ Very Satisfied

\section{Discussion}

The Structure and General Characteristics of Occupational Adaptation of Vocational College Graduates

This study proposes and validates the structural model of occupational adaption of vocational college graduates, which is composed of occupational cognitive adaptation, occupational psychological adaptation, occupational skills adaptation, interpersonal and professional environment adaptation. Among them, occupational cognitive adaptation reflects the adaptation to current career goals, attitudes, teams and so on, psychological adaptation reflects the emotional adaptation to the current work content, way, atmosphere and so on, occupational skills adaptation reflects the adaptation of knowledge and technology to the current vocational needs, interpersonal and professional environment adaptation reflects the adaptation to the satisfing income and that of graduates with general income satisfaction $(P<0.01)$. There are significant differences between the psychological adaptation of graduates with very dissatisfied income and graduates with relatively satisfing income and that of graduates with general income satisfaction $(P<0.01)$. There are significant differences between the interpersonal and professional environment adaptation of graduates with general income satisfaction and graduates with relatively satisfing income and that of graduates with very dissatisfied income $(P<0.01)$ (see Table 5).

complex interpersonal relationship in work and the surrounding professional environment.Although the 22 items of occupational adaptation measure compiled by Tang (2009) were used as the initial scale of this study,there is great difference between the fourdimensional model of this study and the fourdimensional model of Tang (2009) while the latter includes four dimensions with different connotations: occupational skills adaptation (4 items), interpersonal relationship adaptation (4 items), occupational cognitive adaptation (4 items) and occupational objective environment adaptation (4 items)(see appendix).

On the whole, the average value of occupational adaptation of vocational college graduates is 3.22 scores of 5 -subscales, and the adaptation level is in the lower middle state. According to the scores of various factors of occupational adaptation, interpersonal and professional environment adaptation is the best, 
which reflects that graduates have a relatively high degree of acceptance and compliance with professional norms, and they can communicate harmoniously with colleagues, friends, and superiors in their work. The second is the occupational cognitive adaptation, which reflects the vocational planning of vocational college graduates is relatively clear. The correct cognition of occupation has a direct impact on the individual's work direction and goal. To improve occupational adaptability, it is necessary to accurately evaluate and understand their professional interest, ability, and personality. Comparatively speaking, the average scores of the occupational skills adaptation and psychological adaptation of graduates of higher vocational colleges are both low, it is related to the poor quality of students in vocational colleges, the lack of learning initiative of students in vocational colleges, the need to explore and improve the training mode of talents in vocational colleges, and the psychological maladjustment of graduates caused by the gap between ideal and reality.

Gender Differences in Occupational Adaptation of Vocational College Graduates

This study shows that there is no significant difference between men and women in occupational adaptation and its various factors, which is inconsistent with the findings of Tang (2009). The reason may be related to the research object, the former is the higher vocational graduates, the latter is the postgraduates, and the two research objects have been in different educational levels in the domestic higher education system. When they move to work, the former belongs to skilled talents, the latter belongs to technical and engineering talents, and the former is less challenging, and competitive. As for the graduates of higher vocational colleges, there is no significant difference between men and women in occupational adaptation and its factors.

The Difference of Working Yearsin Occupational Adaptation of Higher Vocational College Graduates

Working years is an important variable to study career development and career maturity.According to the teaching age, some researches have divided the professional development of teachers into different stages. For example, Liu (2002) divided the first year of teaching into the survival stage, the second to the fourth year into the adaptation stage, and the fifth year into the mature stage.Similar to teachers' career experience, this study found that occupational adaptation of vocational college graduates reached the lowest level in one year after graduation, and they were in the stage of career survival, but the adaptation of two and three years after graduation was higher than that of just after graduation. Moreover, there was a significant difference between the adaptation of three years after graduation and that of two years after graduation, indicating the improvement of adaptation.

The psychological adaptation reaches the lowest level in one year after graduation, but the psychological adaptation of the two and three years after graduation is higher than that of the first year, and there are significant differences. This may be because college students will experience a stage of adaptation from unfamiliar to familiar after stepping on the job. Employees with a college degree who have worked for more than one year will be more likely to adjust their psychological work state as they gradually become familiar with all aspects of the work and have accumulated work experience and have a grasp of the future.

The Difference in the Nature of Employment Units in Occupational Adaptation of Higher Vocational College Graduates

There are significant differences in the psychological adaptation of vocational college graduates working in units of different natures.Moreover, there is a difference between the psychological adaptation of graduates working in government agencies and state-owned enterprises and that of graduates working in foreign-funded enterprises.It is consistent with the research of Yin (2015), social and economic status is an important environmental variable that affects occupational adaptation. The nature of the employment unit of higher vocational college graduates reflects their social and economic status. Therefore, the psychological adaptation level of higher vocational college graduates working in government-affiliated institutions or social organizations and government agencies is relatively high. The level of psychological adaptation of graduates working in state-owned enterprises is significantly lower than that of graduates working in foreign enterprises, which may be related to the more transparent salary and promotion system of foreign enterprises, while state-owned enterprises are more likely to emphasize education and qualifications, which is not conducive to the career development of higher vocational college graduates with lower degree, and may affect work mentality. Also, graduates working in private enterprises have a high level of psychological adaptation, which also reflects the pragmatic psychology of graduates.

Income Satisfaction Difference in Occupational Adaptation of Higher Vocational College Graduates

With the improvement of the level of income satisfaction, the level of occupational adaptation and its various factors is on the rise. Graduates from higher vocational college with different levels of income satisfaction has significant differences in occupational adaptation, psychological adaptation, interpersonal, and professional environment adaptation. It is consistent with the research of Yin (2015), economic income is one 
of the indicators of social and economic status, which is an environmental variable affecting occupational adaptation. The income level of higher vocational college graduates reflects their social and economic status. The higher the level of income satisfaction is, the higher the social and economic status is, the more positive the occupational adaptation level is.A better income level and a higher social and economic status are likely to lead to a good working attitude. Accordingly, the level of psychological adaptation will be higher.According to Maslow's hierarchy of needs theory, compared with vocational college graduates whose income satisfaction has not reached the general level, vocational college graduates whose income satisfaction has reached the general level have realized their physiological needs and will strive to meet the needs of safety, belonging and love.Therefore, there are significant differences between the interpersonal and professional environment adaptation of graduates with general income satisfaction and graduates with relatively satisfying income and that of graduates with very unsatisfactory income.

\section{Conclusion and Educational THINKING}

This study proposes and validates the theoretical model of occupational adaptation for vocational college graduates, which consists of four dimensions: occupational cognitive adaptation, occupational psychological adaptation, occupational skills adaptation, interpersonal and professional environment adaptation. The study finds that the overall level of occupational adaptation of graduates in higher vocational colleges is low; occupational adaptation is affected by years of graduation, and income satisfaction level; psychological adaptation is affected by years of graduation, unit property, and income satisfaction level; interpersonal and professional environment adaptation is affected by income satisfaction level. From the perspective of analysis, the level of occupational adaptation of vocational college graduates is generally low, which is not only an inevitable phenomenon and stage in the process of college graduates' own growth, but also related to the job itself and the environment, as well as the lack of higher vocational college education and management. Therefore, combined with the research, this paper puts forward the following thoughts on employment education and related in vocational colleges.

Deepen the Work of Vocational Guidance and Improve the Vocational Cognition and Occupational Adaptation Level of Graduates

According to the theory of career maturity, the degree of readiness of an individual to make a practical and appropriate career choice before entering a career directly affects the individual's career choice, occupational adaptation, career satisfaction, and the realization of career goals. Vocational college students are in the stage of exploration and establishment of their whole career development. They conduct selfexamination, role appraisal, and career exploration through school learning.Therefore, higher vocational colleges should combine the employment education with the employment guidance work, carry out the employment education according to the subject characteristics of each major, the psychology, and career ideal of the students of each grade, help the students to recognize the employment situation and themselves, carry out the personal career planning based on themselves, and adjust the career planning in time according to the actual situation, so as to prepare for employment before graduation, improve the career maturity of employment choice, and then improve the occupational cognitive adaptation level and adaptation level of vocational college graduates.

Improve the Talent Training Mode of Higher Vocational Colleges and Improve the Occupational Skills Adaptation Level of Graduates

To improve the talent training mode of higher vocational colleges is helpful to improve the occupational skills adaptation level of graduates. First of all, we should conduct extensive social research and clarify the goal of talent training. Based on extensive research on the needs of employers, with the cooperation of colleges and enterprises, the two levels of colleges and departments jointly discuss and determine the professional training programs that meet the needs of professional development, strengthen practical teaching, and combine curriculum teaching with work posts. Secondly, we should reform teaching methods and means to improve teaching quality. The project-driven teaching method is adopted as the teaching method, supplemented by other teaching methods, and under the mode of Internet sharing education, efforts are made to realize the organic integration of online and offline mixed teaching mode. Thirdly, in the practical teaching process, we should adhere to the industry and education, the cooperation of colleges and enterprises, meanwhile establish a new relationship between famous teachers and students to cultivate students' awe of occupation and dedication to skills and make students have a sense of occupation sanctity and mission.Finally, we should strengthen the construction of "double qualified teachers" teaching staff, and strive to build a high-quality teaching staff with an excellent political quality, professional ability, and teaching level. The high-quality teaching staff is not only the premise and guarantee of training the skilled professional talents but also can guide the students to choose the job and improve their occupational adaptation. 
Strengthen the Mental Health Education of Students and Improve the Level of Occupational Psychological Adaptation of Graduates

Among the factors of occupational adaptation, the level of psychological adaptation of vocational college graduates is the lowest, which is affected by the graduation year, the nature of the unit, and the level of income satisfaction. Therefore, it is urgent to strengthen the mental health education of vocational college students, help them solve mental health problems, and promote the overall improvement of the quality of vocational college students.In the mental health education of higher vocational colleges, we should pay attention to the integration of mental health education into professional disciplines, curriculum and daily life, to form a system of mental health education, which is normative and scientific.At the same time, strengthening the construction of mental health education teaching staff is the premise and guarantee of mental health education. The establishment of the mental health education system and the related teaching staff will help to improve the level of psychological adaptation of the graduates.

Carry Out Vocational Spirit Education and Guide Vocational College Students to Establish Correct Values The level of income satisfaction affects the occupational adaptation, psychological adaptation, interpersonal and professional environment adaptation of vocational college graduates. Therefore, higher vocational colleges need to strengthen the education of students' ideal and belief, guide students with correct values, make them correctly understand the relationship between salary treatment and development prospect, interpersonal relationship, work stability, self-realization, so as to establish an ideal and a correct outlook on employment and success, and cultivate the professional spirit of love, dedication, hard work, cooperation and mutual assistance.

Appendix

\begin{tabular}{|c|c|}
\hline \multicolumn{2}{|c|}{ Occupational Adaptation for Postgraduates (Tang,2009) } \\
\hline \multirow{4}{*}{ Occupational Skills Adaptation } & I can face difficulties calmly because I believe in my ability to deal with problems \\
\hline & When facing a difficult problem, I can usually find several solutions \\
\hline & I often feel weak and uncomfortable \\
\hline & I am confident in achieving my work goals \\
\hline \multirow{4}{*}{ Interpersonal Relationship Adaptation } & I sometimes feel be misfits with my surroundings \\
\hline & I feel a lot of pressure at work \\
\hline & I feel at a loss about the relationships around me \\
\hline & I can resolve conflicts with others \\
\hline \multirow{4}{*}{ Occupational Cognitive Adaptation } & I have clear career goals and career plans \\
\hline & I am often confused about my work and prospects \\
\hline & I often have the idea of changing my job \\
\hline & I am often tired of my work \\
\hline \multirow{4}{*}{ Occupational Objective Environment Adaptation } & Income is hard to meet the needs of an ideal life \\
\hline & Working environment and conditions is unsatisfactory \\
\hline & I am unable to adapt to the climate, customs and etc. of the location of the unit \\
\hline & Career stability is too bad, I have no sense of security \\
\hline
\end{tabular}

References Références Referencias

1. Xiao Gan.2014.Investigation Analysis and Educational Enlightenment on the Phenomenon of Frequent Job Hopping of College Students' Employees in the Period of Occupational Adaptation. Research on Chinese Youth, 3:84-88, 83.

2. Fang Li-luo. 2001. Professional Psychology and Successful Job Hunting. Beijing: Mechanical Industry Press.

3. Dai Rui. 2002. New Teachers' Maladjustment and its Prevention. Educational exploration, 4:95-97.

4. Pan Zi-ying.2013.On the study of occupational adaptability. Research on Continuing Education, 11:134-140.

5. Veenman S. 1984. Perceived Problems of Beginning Teachers. Review of Educational Research, 54(2):143-178.
6. Yuan Fang, Yao Yu-qun, Chen Yu.1992. Labor Sociology. Beijing: China Labor press.

7. Chen Hui-chang. 1999. A Study on the Personality Psychology of Students in the Period of Moral Education. Beijing: Chinese press.

8. Campell J P.1990. Modeling the Performance Prediction Problem in Industrial and Organizational Psychology. Palo Alto CA: Consulting Psychologists Press.

9. Huebner R A, Emery L J, Shordike A. 2002. The Adolescent Role Assessment: Psychometric Properties and Theoretical Usefulness. American Journal of Occupational Therapy, 2:34-67.

10. Savickas M L, Porfeli E J. 2012. Career Adaptabilities Scale: Construction, Reliability, and Measurement Equivalence Across 13 Countries. Journal of Vocational Behavior, 50:661-673.

11. Wang Qi. 2018. A Study on the Relationship between Organizational Support and Job 
Satisfaction of Teachers in Higher Vocational Colleges: the Mediation of Occupation Adaptation. Research on Higher Education in China, 9:104-108.

12. Yin Yu-xin. 2015. A Study on the Relationship between Social and Economic Status and New Teachers' Entry Adaptation. Journal of the State Education Administration College, 9:77-83.

13. Tang Xue-mei. 2009. A Study on the Occupational Adaptability of Postgraduates: Take Chengdu University graduates as an example. Chengdu: Southwest Jiaotong University.

14. Nunnally J C. 1978. Psychometric Theory. New York: McGraw-Hill.

15. Liu Jie. 2002. Professionalization: Teachers Challenging the 21st Century.Beijing: Education Science Press. 